\title{
Nuclear DNA variation in diploid and polyploid taxa of Larrea (Zygophyllaceae)
}

Lidia Poggio,

Alicia D. Burghardt* and

J. H. Hunziker* +
* Departamento de Ciencias Biológicas, Facultad de Ciencias Exactas y Naturales, 1428 Buenos Aires, Argentina.

† Instituto de Botánica Darwinion. C.C. 22, 1642 San Isidro, Argentina.

A study of nuclear DNA content was made in telophase nuclei (2C) of the root apex of germinating seed in nine populations of the following species and cytotypes of Larrea: $L$. nitida $(2 x)$, L. divaricata $(2 x)$, L. cuneifolia $(4 x)$ and L. tridentata $(2 \mathrm{x}, 4 \mathrm{x}, 6 \mathrm{x})$. There were no significant differences in DNA content per basic monoploid genome among the diploid taxa nor between the latter and the tetraploid, among tetraploids or between tetraploids and the hexaploid. On the other hand, the difference between means was significant when all diploids were compared with the hexaploid cytotype. These results would indicate:

(1) Speciation at the diploid level in Larrea has not produced great differences in DNA content per basic genome. This is in contrast with the related genus Bulnesia.

(2) In Larrea there is a slight diminution in DNA content per basic genome when there is an increase in ploidy level.

(3) Species of Larrea, Bulnesia and Pintoa (Zygophyllaceae) that inhabit the most arid environments are the ones possessing the highest DNA content.

(4) This increase is due to an increment in ploidy level in Larrea and an augment of intrachromosomal DNA in Bulnesia and Pintoa.

\section{INTRODUCTION}

The genus Larrea has an interesting disjunct amphitropical distribution covering arid and semiarid regions of Argentina, Chile, Bolivia, Perú, México and Southwestern United States. It is subdivided into two taxa: Sect. Larrea, comprising the South American diploid $(2 n=26)$ multifoliolate species $L$. nitida and L. ameghinoi and Sect. Bifolium, which includes bifoliolate species such as the South American "jarillas" L. divaricata, diploid, and L. cuneifolia, tetraploid $(2 n=52)$, and the North American "gobernadora" or "creosote bush" L. tridentata. This last taxon comprises a diploid cytotype $(2 n=26)$, occurring in the Chihuahuan desert, a tetraploid $(2 n=52)$ in the Sonoran desert, and an hexaploid $(2 n=78)$ in the Mohave desert (Hunziker et al. 1977, 1978).

The three cytotypes have almost exclusively an allopatric distribution and there is a correlation between the increase in ploidy level and the increment in aridity, the Mohave desert being the most extreme. Tetraploid and hexaploid populations would have originated through interracial autopolyploidy (Hunziker et al., 1972, 1978; Yang et al., 1977).

Bennett (1976, 1987) has suggested that interspecific variation in DNA content has adaptive significance and is correlated with the environment and the geographical distribution. In the present investigation the $2 \mathrm{C}$ DNA content of $L$. nitida, $L$. divaricata, L. cuneifolia and the three cytotypes of L. tridentata is studied. An analysis is attempted of the variations that might have occurred during speciation and the possible correlation with adaptation to arid environments.

\section{MATERIALS AND METHODS}

The seed was usually collected from 25 randomly chosen individuals in each population. Representative herbarium specimens are deposited at the herbaria of the Facultad de Ciencias Exactas y Naturales, Universidad de Buenos Aires (BACFC), the Missouri Botanical Garden (MO) and the Instituto de Botánica Darwinion (SI). 
Abbreviations correspond to J. H. Hunziker (JHH) and A. D. Burghardt (ADB).

The origin of the materials is as follows:

L. nitida. Argentina, Prov. Mendoza, Depto. Las Heras, Between Punta de Vacas and Arroyo El Tambillito, $2200 \mathrm{~m}$ elevation. JHH 9870.

L. divaricata. Argentina, Prov. Río Negro, Depto. San Antonio, Las Grutas, $20 \mathrm{~m}$ elevation. ADB 31. Argentina, Prov. La Pampa, Depto. Caleu Caleu, Anzoategui, $100 \mathrm{~m}$ elevation. ADB 5.

L. cuneifolia. Argentina, Prov. La Rioja, Depto. Capital, Near the airport and Río de la Rodadera, $500 \mathrm{~m}$ elevation. JHH 9723.

Argentina, Prov. Río Negro, Depto. San Antonio, Route 251, $9 \mathrm{Km}$ North of junction of routes 3 and 251 . ADB 52 .

L. tridentata. (2x). U.S.A., Arizona, Mountview., ca. 25 miles SE of Tucson, $3550 \mathrm{ft}$. Col. T. W. Yang.

L. tridentata. (4x). U.S.A. Arizona, Tucson, Bellevue, $2490 \mathrm{ft}$. Col. T. W. Yang.

L. tridentata. $(6 \mathrm{x})$. U.S.A., California, San Bernardino Co., Victorville, Vacant lot, 200-300 $\mathrm{m}$ from hotel. JHH 10025. U.S.A., Nevada, Nye Co., route 95, between Tonopah and Scotty's junction, 52 miles South of Tonopah. JHH 10026.

DNA content was measured in telophase nuclei (2C) at the root apex of germinating seed. For germination, seeds were placed in petri dishes on wet filter paper. Roots of $0 \cdot 5-1 \mathrm{~cm}$ length were fixed in 3 absolute ethanol: 1 acetic acid during 1-4 days. Allium cepa roots were used as a standard. After fixation, the roots were rinsed 30 minutes in distilled water. Hydrolysis was carried out with $5 \mathrm{~N} \mathrm{HCl}$ at $20^{\circ} \mathrm{C}$ (Deitch et al., 1968; Fox, 1969). Different times of hydrolysis were investigated and the optimum period determined was 50 minutes. After hydrolysis, the material was rinsed three times with distilled water for 10 or 15 minutes.

Staining was carried out with Feulgen stain at $p$ H $2 \cdot 2$ for 2 hours (Teoh and Rees, 1976). The material was then rinsed three times in $\mathrm{SO}_{2}$ water for 10 minutes each rinse, then rinsed again with distilled water (5 to 15 minutes) and, finally, squashed in 45 per cent acetic acid. The coverslip was removed after freezing with $\mathrm{CO}_{2}$ and the material was dehydrated in absolute alcohol and mounted in euparal.

The amount of Feulgen staining per nucleus, expressed in arbitrary units, was measured at a wavelength of $570 \mathrm{~mm}$ using the scanning method in a Zeiss Cytoscan. The basic genome DNA content expressed in pg was calculated using Allium cepa as a standard $(2 \mathrm{C}=33.5 \mathrm{pg}$; Bennett and Smith, 1976). The differences in DNA content between populations and species were tested through an analysis of variance and comparisons between means using the Games and Howell method (Sokal and Rohlf, 1981) or Scheffé's method (Scheffé, 1959).

Chromosome studies were based on squashes from root tips pretreated with saturated aqueous solution of paradichlorobenzene and fixed in a 3 ethyl alcohol: 1 acetic acid solution. After maceration in $5 \mathrm{~N} \mathrm{HCl}$ at $20^{\circ} \mathrm{C} ; 2$ per cent acetic haematoxylin was used for staining.

\section{RESULTS}

Chromosome numbers were determined for all strains. $L$. divaricata and $L$. cuneifolia were found to be diploid and tetraploid as expected and this confirmed several counts from different regions of their range made previously on these species (Hunziker et al., 1978). The chromosome numbers obtained in $L$. tridentata agree with the innumerable cytological determinations made by Yang $(1967,1968,1970)$ and confirms the diploid, tetraploid and hexaploid nature of the Chihuahuan, Sonoran and Mohave cytotypes, respectively (Yang et al., 1977).

Table 1 Nuclear DNA content in different populations of Larrea divaricata $(2 \mathrm{x})$, L. cuneifolia $(4 \mathrm{x})$ and $L$. tridentata $(6 \mathrm{x})$

\begin{tabular}{|c|c|c|c|c|}
\hline Species & Population & $\begin{array}{l}\text { DNA content }(2 \mathrm{C}) \\
\text { (A.U.) }\end{array}$ & $\begin{array}{l}\text { No. of } \\
\text { nuclei }\end{array}$ & $G \& H(1)$ \\
\hline \multirow{2}{*}{$\begin{array}{l}\text { L. divaricata } \\
(2 \mathrm{x})\end{array}$} & $\mathrm{ADB} n^{\circ} 31$ & $1.416 \pm 0.067$ & 24 & \multirow[t]{2}{*}{$2 \cdot 946 \mathrm{NS}^{\mathrm{a}}$} \\
\hline & $A D B n^{\circ} 5$ & $1.728 \pm 0 \cdot 082$ & 17 & \\
\hline \multirow{2}{*}{$\begin{array}{l}\text { L. cuneifolia } \\
(4 \mathrm{x})\end{array}$} & $\mathrm{ADB} \mathrm{n}^{\circ} 52$ & $2.217 \pm 0.115$ & 14 & \multirow[t]{2}{*}{$1 \cdot 171 \mathrm{NS}^{\mathrm{b}}$} \\
\hline & $\mathrm{JHH} \mathrm{n}^{\circ} 9723$ & $2 \cdot 523 \pm 0 \cdot 227$ & 16 & \\
\hline \multirow{2}{*}{$\begin{array}{l}\text { L. tridentata } \\
(6 \mathrm{c})\end{array}$} & $\mathrm{JHH} \mathrm{n}^{\circ} 10025$ & $3 \cdot 042 \pm 0 \cdot 120$ & 34 & \multirow[t]{2}{*}{$1.832 \mathrm{NS}^{\mathrm{b}}$} \\
\hline & $\mathrm{JHH} \mathrm{n}^{\circ} 10026$ & $3 \cdot 541 \pm 0 \cdot 244$ & 12 & \\
\hline
\end{tabular}

Level of significance: $\alpha=0 \cdot 01^{\mathrm{a}} ; \alpha=0 \cdot 05^{\mathrm{b}}$.

(1) Games and Howell method, program MCHETV, Sokal and Rohlf (1981). 
Table 2 Nuclear DNA content in populations of species of Larrea

\begin{tabular}{|c|c|c|c|c|c|c|c|}
\hline \multirow[b]{2}{*}{$\begin{array}{l}\text { Species or } \\
\text { cytotype }\end{array}$} & \multirow[b]{2}{*}{$\begin{array}{l}\text { Ploidy } \\
\text { level }\end{array}$} & \multirow[b]{2}{*}{$2 n$} & \multirow[b]{2}{*}{$\begin{array}{l}\text { No. of } \\
\text { nuclei }\end{array}$} & \multicolumn{2}{|l|}{$\begin{array}{l}\text { DNA content } \\
(2 \mathrm{C})\end{array}$} & \multicolumn{2}{|c|}{$\begin{array}{l}\text { DNA per basic } \\
\text { genome }\end{array}$} \\
\hline & & & & $\begin{array}{l}X \pm \text { S.E. } \\
\text { (A.U.) }\end{array}$ & pg. & A.U. & pg. \\
\hline L. nitida & $2 x$ & 26 & 60 & $1.557 \pm 0.090$ & $1 \cdot 625$ & 0.779 & 0.813 \\
\hline L. divaricata & $2 x$ & 26 & 41 & $1 \cdot 545 \pm 0.056$ & $1 \cdot 614$ & 0.773 & 0.807 \\
\hline L. tridentata & $2 x$ & 26 & 38 & $1.439 \pm 0.086$ & $1 \cdot 502$ & 0.719 & 0.751 \\
\hline L. tridentata & $4 x$ & 52 & 60 & $2 \cdot 436 \pm 0.072$ & $2 \cdot 543$ & 0.609 & 0.636 \\
\hline L. cuneifolia & $4 x$ & 52 & 30 & $2 \cdot 380 \pm 0 \cdot 136$ & $2 \cdot 485$ & 0.595 & 0.621 \\
\hline L. tridentata & $6 x$ & 78 & 46 & $3 \cdot 173 \pm 0 \cdot 113$ & $3 \cdot 313$ & 0.529 & 0.552 \\
\hline
\end{tabular}

DNA contents in arbitrary units and in picograms are summarized in tables 1 and 2 . Figure 1 shows the frequency histograms of the species and cytotypes indicating the number of nuclei studied and their DNA content in arbitrary units. For each population 2 or 3 replicates were made which presented nonsignificant differences.

In $L$. divaricata (diploid), L. cuneifolia (tetraploid) and $L$. tridentata (hexaploid) two populations from different localities were studied (table 1. In the three species, using an approximate test of equality of means (Games and Howell method, Sokal and Rohlf, 1981) the differences between averages of different populations of each species were non significant. As a consequence data were pooled for each species in table 2 .

An analysis of variance for the DNA content per basic genome of the species listed in table 2 indicates that there are significant differences among the taxa $\left(F=9 \cdot 776, \quad P<10^{-7}\right)$. Comparisons made through Scheffé's method indicated that there are no significant differences in DNA content per basic genome either among diploids or between the tetraploids $L$. cuneifolia and $L$. tridentata. There are no significant differences either when the following pairwise comparisons are made: (1) L. tridentata (diploid) with $L$. tridentata (tetraploid) and (2) L. tridentata (tetraploid) with L. tridentata (hexaploid). On the other hand, the difference between means was significant when each diploid was compared separately with the hexaploid cytotype of $L$. tridentata. These results would indicate that there is a slight diminution in DNA content per basic genome when there is an increase in ploidy level.

For evaluating the variation in DNA content, $2 \mathrm{C}$ and per basic genome, in relation to ploidy level, a regression variance analysis was made. In both cases linear regression was highly significant and the results that were obtained are represented in fig. 2. The $2 \mathrm{C}$ DNA content increases sig- nificantly with ploidy level $(y=0.64+0.43 x ; F=$ 98.62; $P<10^{-10}$ ) but the estimated regression line has a gentler slope than a calculated hypothetical line, which assumes that when the number of genomes increases, DNA is added as an exact multiple of the DNA content per basic genome (fig. 2(A)). This difference is correlated with the obtention of a negative regression when DNA content per basic genome is plotted against ploidy level $\left(y=0.81-0.047 x ; F=97 \cdot 76 ; P<10^{-11}\right.$; fig. 2(B)).

In fig. 3 the $2 \mathrm{C}$ DNA content is plotted against ploidy level for the species of Larrea studied here and for the related genera Bulnesia (Poggio and Hunziker, 1986) and Pintoa (Poggio and Naranjo, in press).

\section{DISCUSSION}

Within the genus Larrea the multifoliolate group (Sect. Larrea) is the most primitive and comprises the two diploid species $L$. ameghinoi and $L$. nitida, having 3-16 leaflets. The supposedly more advanced group Sect. Bifolium consists of bifoliolate ( $L$. divaricata $(2 n=26), L$. cuneifolia $(2 n=52)$ and $L$. tridentata $(2 n=26,52,78))$ which have their leaves reduced to only one pair of leaflets. The bifoliolate species seem to represent a reductional trend in response to aridity (Hunziker et al., 1977).

The DNA $2 \mathrm{C}$ contents of $L$. nitida and $L$. divaricata (table 2), both diploid, but one from the primitive section and the other from the more advanced, respectively, do not differ significantly. L. divaricata has a much wider distribution (Hun. ziker et al., 1977, figs. 2.3 and 2.1) and has a wider range of habitats. $L$. nitida is restricted to the coolest and more humid habitats of the whole range occupied by $L$. divaricata. DNA content in Patagonian $L$. ameghinoi was not studied because 


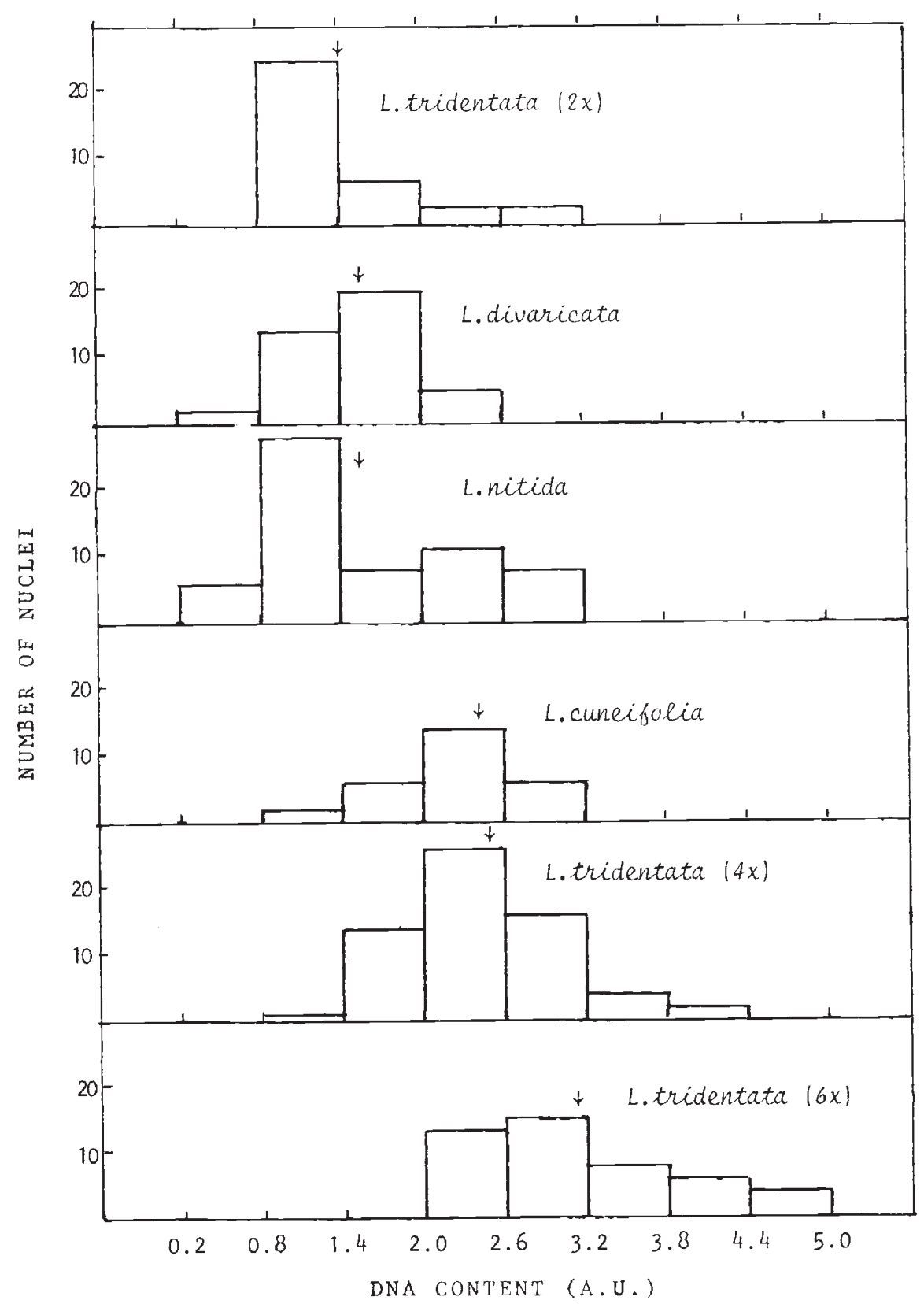

Figure 1 Frequency histograms: 2C DNA content in arbitrary units (A.U.) plotted against number of nuclei.

of lack of viable seed but it is likely that its content does not differ greatly from that found in L. nitida since their natural hybrid is completely fertile, shows normal meiosis with good pairing, without noticeable heteromorphic bivalents and both taxa could be considered partially sympatric semispecies (Hunziker et al., 1978). The morphological and physiological variations producing adaptation to aridity and other rigorous conditions (low temperatures, wind, etc) in the diploid species of Larrea are apparently not correlated with great variation of their DNA content. We may conclude that, speciation at the diploid level in Larrea has not produced great differences in DNA content 

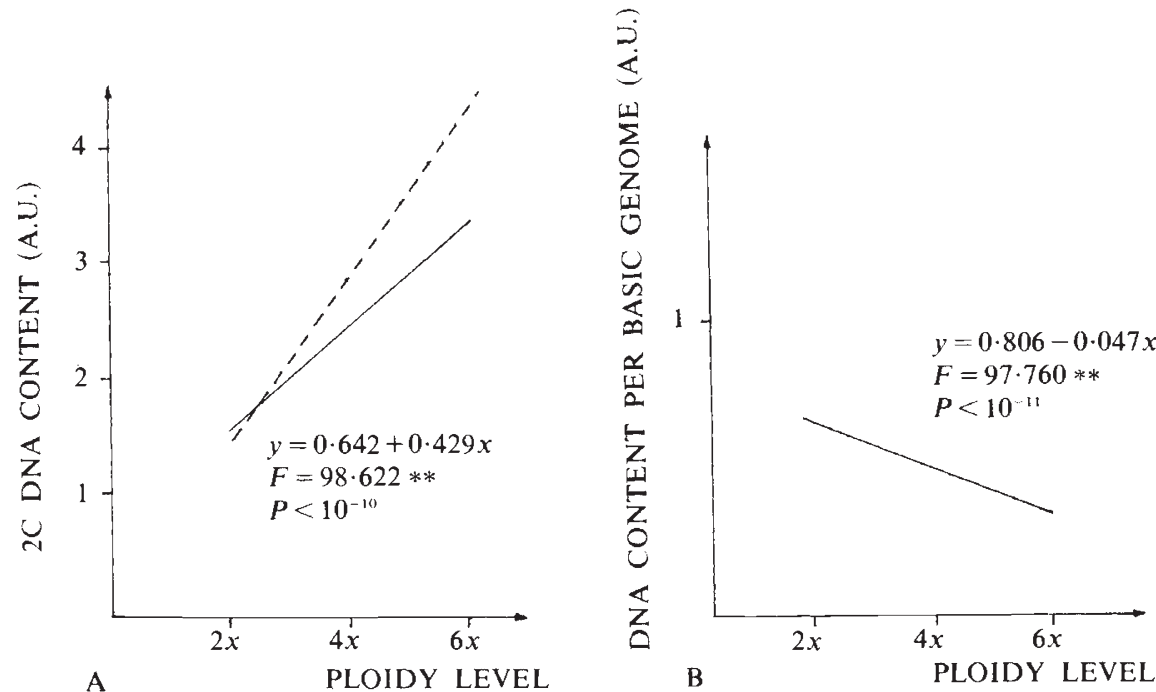

Figure $2 \mathrm{~A}=$ Regression $2 \mathrm{C}$ total DNA content on ploidy level in cytotypes of Larrea. Solid line $=$ observed, broken $=$ expected regression. $\mathrm{B}=\mathrm{DNA}$ content per basic genome plotted against ploidy level (regression line)

per basic genome. The opposite has occurred in the closely related genus Bulnesia (Poggio and Hunziker, 1986; Poggio et al., 1986).

On the other hand, when the DNA contents per basic genome of tetraploid $L$. cuneifolia and tetraploid and hexaploid cytotypes of $L$. tridentata are analyzed a slight tendency towards diminution is observed when there is an increase in polyploidy (table 2, fig. 2(B)).

Even when a stronger compaction of DNA in polyploid nuclei produces an underestimate of the measurements (Verma and Rees, 1974; Kenton, $1984 b$ ) it has been observed in several cases that polyploids have smaller chromosomes and lower DNA content than the expected (Darlington, 1965; Grant, 1976, 1987; Bennett, 1987; Martínez and Ginzo, 1985; Poggio and Hunziker, 1986; Poggio and Naranjo, in press). In Larrea due to the very small size of its chromosomes it is not known whether the diminution affects all chromosomes or only part of the complement. DNA content per basic genome in the diploid taxa of Larrea $(0.75-$ $0.81 \mathrm{pg}$, see table 2) is slightly higher than the content of the species that Palacios and Hunziker (1984) considered as primitive in the closely related genus Bulnesia (B. schickendantzii and B. foliosa, $0.58 \mathrm{pg}$ and $0.50 \mathrm{pg}$, respectively; Poggio and Hunziker, 1986). In Bulnesia octoploid B. bonariensis has the smallest DNA content per basic genome and the smallest chromosomes (Poggio and Hunziker, 1986; Poggio et al., 1986).

The DNA content of autotetraploid L. tridentata does not differ from that of $L$. cuneifolia. The latter species is an allopolyploid, one of its parental diploids being $L$. divaricata and the other a now extinct and unknown diploid (Hunziker et al., 1978).

The similarity of DNA content in these auto and allotetraploid taxa would indicate either that DNA per genome has decreased in like manner at the tetraploid level or that some of the ancestral diploids had lower DNA content than present day diploids.

Two alternative explanations have been offered to explain why polyploid taxa may have less DNA per basic genome than the diploids. According to one, the polyploids could have been originated by diploids, perhaps extinct at present, that possessed lower DNA content.

These diploids, having the smallest chromosomes, would have been preadapted to give rise to polyploids (Darlington, 1956).

Another explanation is that saltatory changes occurred in the genome (DNA reduction) and this could have happened at the diploid or polyploid level (Grant, 1987).

The fact that interracial autotetraploids of $L$. tridentata have less DNA content per basic genome than the related diploids ( $L$. tridentata, $L$. divaricata) suggests that the elimination of DNA has occurred in the polyploids and not in their ancestral diploids. It could be postulated that at polyploid level, the DNA elimination leads to a more adequate balance between total DNA content and a certain cellular parameter. Moreover, at the polyploid level, with genetic material dupli- 


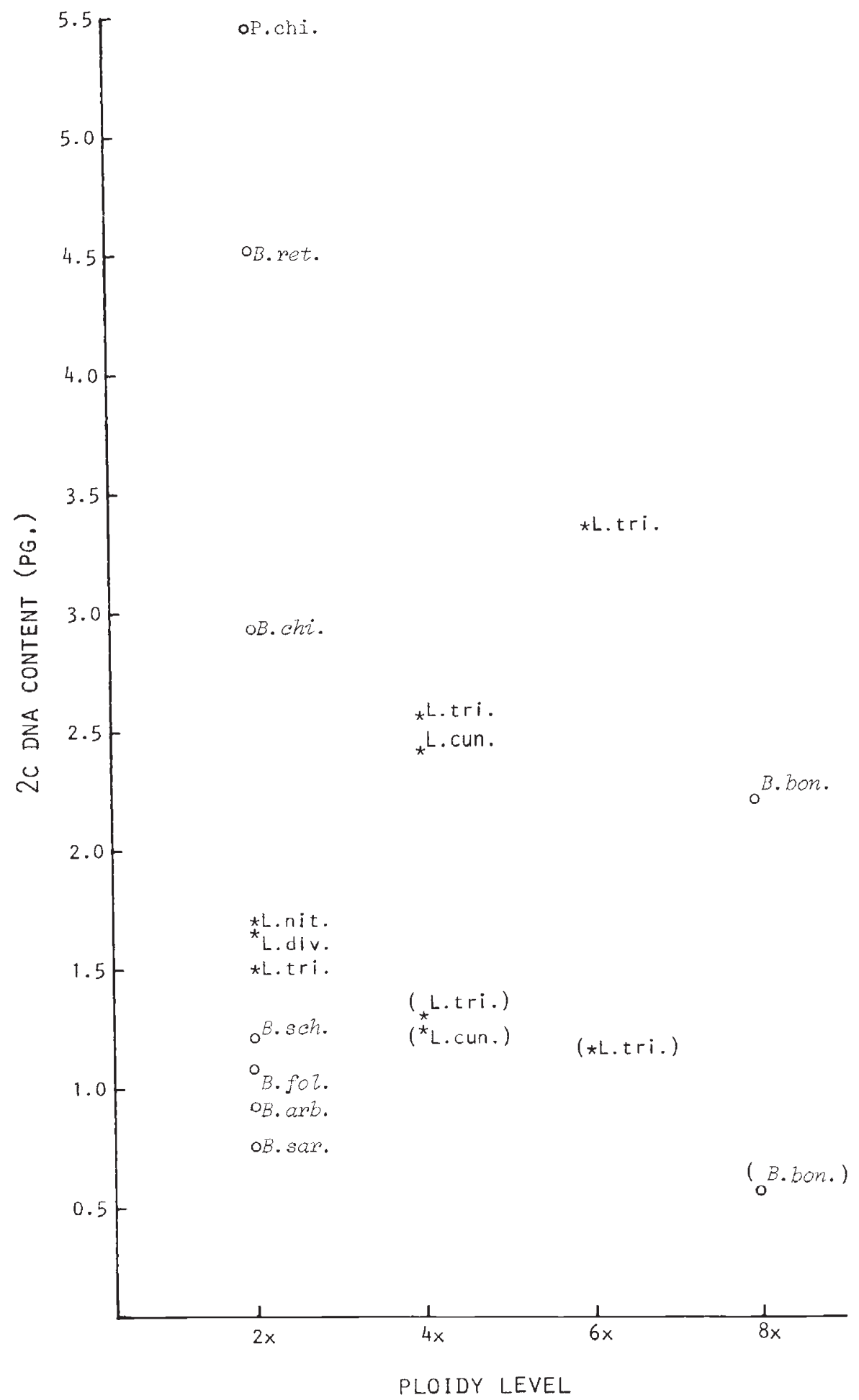

Figure $32 \mathrm{C}$ total DNA content plotted against ploidy level in cytotypes and species of Bulnesia (from Poggio and Hunziker, 1986), Pintoa (from Poggio and Naranjo, in press) and Larrea. Betwecn parenthesis the DNA content per diploid genome. Abbreviations are as follows: Bulnesia $=$ B. arb. $=$ B. arborea; B. bon. $=$ B. bonariensis; B. chi $=$ B. chilensis; B. fol. $=$ B. foliosa; B. ret. $=$ B. retama; B. sar. $=$ B. sarmientoi; B. sch. $=$ B. schickendantzii. Larrea $=$ L. cun. $=$ L. cuneifolia; L. div. $=$ L. divaricata; L. nit. $=L$. nitida $;$ L. tri. $=L$. tridentata. Pinto $a=$ P. chi. $=P$. chilensis. 
cated, the partial elimination of DNA material is more easily tolerated.

In $L$. tridentata the ploidy level and therefore the total DNA content increases towards the west with a concomitant increase in aridity (Hunziker et al., 1977, 1978). If total DNA content of Zygophyllaceae of the genera Larrea, Bulnesia and Pintoa is compared (fig. 3) it can be seen than those species that inhabit the most arid environments (B. retama, B. chilensis, $P$. chilensis, $L$. tridentata $6 \mathrm{x})$ are the ones possessing highest DNA content. This increase is due to an increment in ploidy level in Larrea and an augment of intrachromosomal DNA in Bulnesia and Pintoa (Poggio and Hunziker, 1986; Poggio and Naranjo, in press).

It is possible that changes in DNA content can influence the ecological properties of species. Increased repetitive DNA may play an important role in gene regulation while gene duplication may increase ecological amplitude because of fixation of different alleles at loci having equal function or through the acquisition of new genic functions, (Levin and Funderberg, 1979). It is interesting to point out, however, that in both cases (increment in ploidy level and intrachromosomal DNA) nucleotypic parameters are altered whose expression is more a function of total DNA content than the informational content (Bennett, 1987). Moreover, if DNA variation is correlated with morphological or ecological diversity it would seen likely to be adaptive (Kenton, 1984a). The results obtained in Bulnesia, Pintoa and Larrea suggest that there is a correlation between environmental factors and total DNA content and that the latter may have adaptive significance.

Acknowledgements The authors wish to express their gratitude to Dr. Tien Wei Yang for furnishing seed of the diploid and tetraploid cytotypes and to Lic. Beatriz González for statistical advice. They also would like to thank the "Comisión Nacional de Energía Atómica" and the "Consejo Nacional de Investigaciones Cientificas y Técnicas", both of Argentina for the use of the microdensitometer and for several grants, respectively.

\section{REFERENCES}

BENNETT, M. D. 1976. DNA amount, latitude and crop plant distribution. In Jones, K. and Brandham, P. (eds.) Current Chromosome Research, Elsevier North-Holland Biomedical Press, Amsterdam, pp. 151-158.

BENNETT, M. D. 1987. Variation in genomic form in plants and its ecological implications. New Phytol. 106 (Suppl), $177-$ 200 .
BENNETT, M. D. AND SMITH, J. B. 1976. Nuclear DNA amount in Angiosperms. Proc. R. Soc. London B, 274, 227-274.

DARLington, C. D. 1956. Chromosome Botany. G. Allen and Unwin Ltd. London.

DARLINGTON, C. D. 1965. Cytology. Churchill, Ltd. London. DEITCH, A. D., WAGNER, D. AND RICHARD, R. M. 1968. Conditions influencing the intensity of the Feulgen reaction. $J$. Histochem. Cytochem., 16, 371-379.

FOX, D. P. 1969. Some characteristics in the cold hydrolysis technique for staining plant tissues by the Feulgen reaction. J. Histochem. Cytochem., 17, 266-272.

GRANT, W. F. 1976. The evolution of karyotype and polyploidy in arboreal plants. Taxon, 25, 75-84.

GRANT, W. F. 1987. Genome differentiation in higher plants. Chapter 1. Urbanska, K. M. (ed.) Differentiation Patterns in Higher Plants. Academic Press. London and N. York, pp. 9-32.

HUNZIKER, J. H. 1975. On the geographical origin of Larrea divaricata (Zygophyllaceae). Ann. Missouri Bot. Gard., 62, 497-500.

HUNZIKER, J. H., PAlacios, R. A., VAlESi, A. G. DE AND POGGIO, L. 1972. Species disjunctions in Larrea: evidence from morphology, cytogenetics, phenolic compounds, and seed albumins. Ann. Missouri Bot. Gard., 59, 224-233.

HUNZIKER, J. H., PALACIOS, R. A., POGGIO, L., NARANJO, C. A. AND YANG, T. W. 1977. Geographic Distribution, Morphology, Hybridization and Evolution. In Mabry, T. J, Hunziker, J. H. and Difeo, O. R. (eds.) Creosote Bush. Biology and Chemistry of Larrea New World Desert. US/IBP synthesis Series No 6. Hutchinson and Ross, Inc. Stroudsburg, Penn. pp. 10-47.

HUNZIKER, J. H., PALACIOS, R. A., VAlESi, A. G. DE AND POGGIO, L. 1978. Hybridization in Larrea (Zygophyllaceae): a morphological cytogenetic and chemosystematic study. Bol. Acad. Ciencias Córdoba., 52, 281-314.

KENTON, A. 1984a. Chromosome evolution in the Gibasis linearis group. (Commelinaceae) III. Chromosoma (Berl.), 90, 303-310.

KENTON, A. 1984b. Use of pollen tetrads for routine DNA densitometry. Heredity, 53, 667-675.

L.EVIN, D. A. AND FUNDERBURG, S. W. 1979. Genome size in Angiosperms: temperate versus tropical species. Amer. Nat. 114, 784-795.

MARTiNEZ, A. AND GINZO, H. D. 1985. DNA content in Tradescantia. Can. J. Genet. Cytol., 27, 766-775.

PALACIOS, R. A. AND HUNZIKER, J. H. 1984. Revisión taxonómica del género Bulnesia. (Zygophyllaceae). Dar winiana, 25, 299-320.

POGGIO, L. AND HUNZIKER, J. H. 1986. Nuclear DNA content variation in Bulnesia. J. Hered., 77, 43-48.

POGGIO, L., WULFF, A. F. AND HUNZIKER, J. H. 1986. Chromosome size, nuclear volume and DNA content in Bulnesia (Zygophyllaceae). Darwiniana, 27, 25-38.

POGGIO, L. AND NARANJO, C. A. Contenido de ADN y evolución en plantas superiores, Acad. Nac. Cienc. Exact., Fís, y Nat. Buenos Aires (In press).

SCHFFFE, H. 1959. The Analysis of Variance. John Wiley, New York.

SOKAL, R. R. ANI ROHLF, F. J. 1981. The Principles and Practice of Statistics in Biological Research. Freeman and Co. San Francisco.

TEOH, S. B. AND REES, H. 1976. Nuclear DNA amounts in populations of Picea and Pinus species. Heredity, 36, $123-$ 137.

VERMA, S. C. AND REES, H. 1974. Nuclear DNA and the evolution of allotetraploid Brassicae. Heredity, 33, 61-68. 
YANG, T. W. 1967. Chromosome numbers in populations of creosotebush (Larrea divaricata) in the Chihuahuan and Sonoran subdivisions of the North American Desert. $J$. Arizona Acad. Sci., 4, 183-184.

YANG, T. W. 1968. A new chromosome race of Larrea divaricata in Arizona. Western Reserve Acad. Nat. Hist. Museum. Spec. Publ., 2, 1-4.
YANG, T. W. 1970. Major chromosome races of Larrea divaricata in North America. J. Arizona Acad. Sci., 6, 41-45.

YANG, T. W., HUNZIKER, J. H., POGGIO, L. AND NARANJO, C. A. 1977. Hybridization between South American "Jarilla" and North American diploid Creosote bush (Larrea, Zygophyllaceae). Plant Syst. Evol., 126, 331-346. 